\title{
FEDERAL INCOME TAX: THE DILEMMA OF THE CASUALTY LOSS DEDUCTION
}

The purpose of mitigating the sharply progressive rate of taxation
with a corresponding system of deduction is frustrated if the applicabil-
ity of a given deduction is not made certain by statutory language or
judicial construction. A significant example is found in the deduction
allowed the individual taxpayer for non-business casualty losses. ${ }^{1}$

\section{Other Casualty}

The I9r3 code allowed a deduction for losses to non-business or non-income producing property resulting from fire, shipwreck, or storm. " In I9r6 the statute was amended to add the words "or other casualty." Congress has never attempted to define the term "other casualty," and efforts to determine its scope have resulted in considerable litigation. Early decisions applying the doctrine of ejusdem generis allowed a deduction only if the loss resulted from a force similar to fire, storm, or shipwreck. ${ }^{4}$ For example, in Charles $N$. Burch ${ }^{5}$ the taxpayer was denied a deduction because damage to his automobile resulting from a traffic accident was deemed not to be within the general classification of "other casualty" as qualified by fire, storm, or shipwreck. ${ }^{6}$ This strict construction of the statute was repudiated in Shearer v. Anderson, ${ }^{7}$ which allowed a casualty loss deduction for damage to an automoible that overturned on an icy highway. Conceivably, the deduction could have been permitted as indirect storm damage. However, the court rejected the Government's contention

\footnotetext{
${ }^{1}$ INT. REV. CODE OF I954, $\$$ I65 (c) (3).

${ }^{2}$ Ch. I6, § IIB, 38 Stat. I 67 .

${ }^{3}$ Ch. $463, \S 5$ (a) (4), 39 Stat. 759 .

'E.g., Daniel F. Ebbert, 9 B.T.A. I402 (1928); Fred J. Hughes, I B.T.A. 944 (1925). And even in more recent cases, the doctrine of ejusdem generis has been adhere to when the court has sought to deny a deduction. Gilbert Formel, 19 P-H Tax Ct. Mem. 710 (1950); Edgar F. Stevens, I6 P-H Tax Ct. Mem. 693 (1947); W. W. Bercaw, 16 P-H Tax Ct. Mem. 28 (1947).

${ }_{4} 4$ B.T.A. 604 (1926).

'The court in Burch stated that the question had been settled by Clinton Graham, I B.T.A. 775 (1925).

7 16 F.2d 995 (2d Cir. 1927). The Shearer decision was followed in W. S. Bronson, 9 B.T.A. I008 (1927), in which the Board of Tax Appeals expressly overruled its prior decisions in Clinton Graham, supra note 6 and Charles N. Burch, 4 B.T.A. 604 (1926).
} 
that the deduction was barred by the doctrine of ejusdem generis, holding that the doctrine pertained to the type of damage as well as to the force causing the damage. Equating an automobile accident to a shipwreck, the court found a congressional intent to permit a deduction for damage to property used by the taxpayer as a means of private transportation. ${ }^{8}$

The next expansion of the definition of "other casualty" came in the form of deductions for termite damage to private residences. In United States v. Rogers, ${ }^{9}$ termite damage was held to be merely another form of deterioration, which is, of course, not deductible. ${ }^{10}$ Drawing upon previous cases not involving termite damage, the court noted :11

The similar quality of loss by fire, storm or shipwreck is in the suddenness of the loss, so that the doctrine requires us to interpret the statute as though it read "fires, storms, shipwrecks or other sudden casualty."

Rosenberg v. Commissioner ${ }^{12}$ was the first case permitting a casualty loss deduction for termite damage to a private residence. Shortly before purchasing a house, the taxpayer had it inspected for termites. Less than one year later termite damage was discovered, and the cost of repair was deducted as a casualty loss. The commissioner's denial of the deduction was upheld by the Tax Court. ${ }^{13}$ The Court of Appeals for the Fifth Circuit reversed. Applying the suddenness test, the court noted that "sudden" is a comparative term and held that damage to Rosenberg's house, while not sudden when compared to damage by fire, was sudden when compared to normal deterioration of the building. ${ }^{14}$

The dissent in Rosenberg emphasized the conceptual difficulties arising from application of the "relative suddenness" doctrine announced by the majority. ${ }^{15}$ If deductions were permitted for all losses resulting from deterioration that is more rapid than normal, there would be no

${ }^{8} I d$. at 996.

' 120 F.2d 244 (9th Cir. 1941).

${ }^{10}$ Matheson v. Commissioner of Internal Revenue, 54 F.2d 537 (2d Cir. 1931).

21 I 20 F.2d at 248 .

19 198 F.2d 46 (8th Cir. 1952).

${ }^{13}$ I 6 T.C. 1360 (1951).

${ }^{14} 198$ F.2d at 50 .

${ }^{25}$ "Throughout, the whole thing [termite activity] is, as the Fay and Rogers cases recognize, 'a gradual process,' and the damage done is 'not a sudden occurrence,' within the concept of what constitutes, from its nature, mode of operation and character of result, a 'casualty' force." I 98 F.2d at 5 I (dissenting opinion). 
conceptual problem. But, the Court of Appeals in permitting a deduction for the termite damage to the Rosenberg house approved prior cases $^{16}$ denying deductions for termite damage. As noted by the dissent ${ }^{17}$ if termite damage is a casualty loss, then it should be deductible at whatever state of destruction the damge is discovered by the taxpayer. $^{18}$

Since a deduction for "rapid" termite damage is now accepted by the Internal Revenue Service, ${ }^{10}$ it is difficult to understand how the present position of denying a deduction for damage caused by rodents, moths, and other pests can be maintained. ${ }^{20}$ This is especially true in that Revenue Ruling $55-327^{21}$ bases the denial of a deduction for moth damage on United States $v$. Rogers, which has now been modified by Rosenberg to permit a deduction if the damage is proven to have occurred within the preceding year. However, in Burns v. United States $^{22}$ the taxpayer was denied a deduction for damage to trees resulting from an attack by disease-bearing beetles. The court, adverting to the Rosenberg case, noted that the damage to the trees was discovered within the specified time limit. Nevertheless, it held that this damage was not within the definition of a casualty loss. As there is no valid distinction between termite damage and damage caused by beetles, it is believed that the court should have allowed the deduction.

The American Law Institute, reflecting what it believes to be the

${ }^{16}$ United States v. Rogers, 120 F.2d 244 (gth Cir. 194I); Charles J. Fay, 42 B.T.A. 206 (1940), aff'd, I20 F.2d 253 (2d Cir. 1941).

${ }^{17} 198$ F.2d at 51 .

${ }^{18}$ Cases subsequent to Rosenburg have allowed a deduction where the time within which the damage occurred was relatively short. Alan M. Winsor, 28 P-H Tax Ct. Mem. 335 (1959); Buist v. United States, 164 F. Supp. 218 (E.D.S.C. 1958); Leslie C. Dodge, 25 T.C. 1022 (1956); Shopmaker v. United States, 119 F. Supp. 705 (E.D. Mo. 1953). But a deduction was denied where the taxpayer knew for several years that the property was infested. Feinstein v. United States, 48 Am. Fed. Tax R. ${ }_{1367}$ (E.D. Mo. 1954).

A practical reason for denying a deduction for damage occurring over a period of several years is that allowance of the total deduction in the year of discovery might give the taxpayer an undeserved advantage. However, this possibility could be eliminated by using something similar to the formula for back pay in reverse and limiting the deduction to the smaller of the total of a pro rata deduction of the years of destruction or the total deduction in the year of discovery.

${ }^{10}$ In Treas. Rel. TIR-142 (March 3, 1959), the Treasury states that it will allow a deduction where a taxpayer shows that the damage is sudden.

${ }^{20}$ Edward W. Banigan, 20 P-H Tax Ct. Mem. 5 II (1951) (rat infestation).

${ }^{2 x}$ 1955-1 CuM. BuLl. 25.

22174 F. Supp. 203 (N.D. Ohio 1959). Accord, Rev. Rul. 55-599, 1957-2 CuM. BuL... 142. 
case law definition of "other casualty" has proposed that "other sudden misfortune" be substituted for that term. ${ }^{23}$ It is apparent, however, that suddenness is not the common denominator of "other casualty." For example, in Robert M. Diggs ${ }^{24}$ the txapayer was denied a deduction as a casualty loss for glassware and china broken by his maid. The loss was unquestionably sudden. While a requirement that the loss be sudden may circumscribe the applicability of the deduction, still the problem of defining "casualty" or "misfortune" remains.

Another interesting aspect of the definition of "other casualty" is the unwarranted addition of a requirement that the force causing the damage be severe. In Ray Durden ${ }^{25}$ the taxpayer was permitted a casualty loss deduction for damage to his house caused by dynamite blasts at a nearby quarry. The court emphasized that the blasts causing the damage were unusually severe, not the normal blasting done at the quarry. If damage to a residence resulting from dynamite blasts is within the definition of other casualty, why should the intensity of the blasts be material? The statute specifically refers to fire, storm, and shipwreck but includes no requirement as to the magnitude of these events. Cases emphasizing that the loss was deductible because it resulted from the wettest month on record, ${ }^{26}$ or the worst drought in the century, ${ }^{27}$ make this same error. If the damage is of the type for which a causalty loss deduction is permitted, the strength of the force causing the damage should be immaterial. ${ }^{28}$

A related difficulty has occurred in the definition of the term "theft," which appears to have been added to section 165 (c)(3) as an

\footnotetext{
${ }^{23}$ ALI, FED. Income TAX STAT. $§ X_{15}$ (d) (Tent. Draft No, 6, 1952).

${ }^{24}{ }_{28}$ P-H Tax Ct. Mem. ${ }^{84}$ (1959).

${ }^{25} 3$ T.C. I (1944).

${ }^{20}$ Delbert P. Hesler, 23 P-H Tax Ct. Mem. 902 (1954).

${ }^{27}$ Buttram v. Jones, 87 F. Supp. 322 (W.D. Okla. I943). See Rev. Rul. 54-85, I954-1 CuM. BuLL. 58.

${ }^{28}$ The court in Ray Durden possibly believed that the taxpayer, by building a home close to an operating quarry, assumed the risk of damage from normal blasting operations. This should not have bothered the court, however, because negligence, unless it is "gross or willful," does not deprive a taxpayer of a deduction for damage to

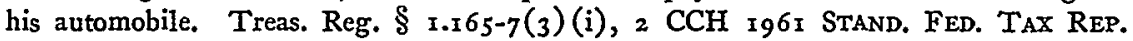
I 1565 . Therefore, unless the taxpayer's act of building in the vicinity of the quarry is equivalent to "gross or willful" negligence, a deduction would be proper if the damage is within the definition of other casualty.

The taxpayer's efforts to establish that the damage was caused by severe blasts were not wasted because this at least served to fix the time of the loss. In addition, the magnitude of the force causing the loss may be some evidence of the extent of the damage.
} 
afterthought. $^{29}$ In general, the courts have adhered to a highly circumscribed definition of loss by theft and have refused a deduction where the loss was occasioned by fraud. For example, in Hanes v. Commissioner $^{30}$ a taxpayer who paid $\$ 2,500$ for a painting that the seller fraudulently represented to be an original attempted to deduct the loss. The court denied the deduction, stating that this was not "theft." From the taxpayer's standpoint there is no difference between loss by theft and loss due to misrepresentation. This position also enjoys conceptual support; modern legal commentators include both misrepresentation and embezzlement within the definition of theft. ${ }^{31}$

At the time section 165 (c) was drafted, damage resulting from fire, storm, or theft might have been particularly burdensome because of the economic loss to the taxpayer. This is not true today because damage resulting from these casualties is generally covered by insurance. In contrast, losses that have been held to be nondeductible often are not included in insurance protection. For example, mortgaged property normally must be protected by insurance covering fire and storm damage, but the mortgagor is seldom required to carry insurance covering damage caused by termites, rodents, or other pests. Although floater type theft insurance policies are not at all uncommon, there is little insurance coverage for lost personal property. If alleviation of economic losses was the rationale for allowing casualty loss deductions, the judicial development of the concept has moved in the opposite direction when the actual economic burden borne by the taxpayer is considered in the light of the development of insurance coverage.

\footnotetext{
${ }^{29}$ The provision for theft losses was not added until 1916. The statutory language was: "Losses . . . arising from fires, storms, shipwreck, or other casualty, and from theft." (Emphasis supplied.) Ch. 463, \& 5 (a) (4), 39 Stat. 759.

${ }^{30} 2$ T.C. $2 \times 3$ ( 1943$)$.

${ }^{31}$ Perkins, ON CRIMINal LAW 272 (1957): "In fact the distinctions between larceny, embezzlement and false pretenses serve no useful purpose in the crimiual law but are useless haudicaps from the standpoint of the administration of criminal justice..." Accord, Hall, Cases and Readings on Criminal LaW and Procedure Ch. 3 (1949).

The regulations have not precluded acceptance of this concept. Treas. Reg. § r.165-8 (3)(d), 2 CCH I96I STAND. FED. TAX REp. I I 570: "For purposes of this section the term 'theft' shall be deemed to include, but shall not necessarily be limited to larcency, embezzlement, and robbery." A recent Tax Court decision, Michele Monteleone, 34 T.C. No. 73 ( (960), permitted taxpayer a deduction for $\$ 28,000$ lost by false pretenses because under California law "false pretenses" is embraced under the statutory definition of theft. Accord, David H. Schultz, 30 T.C. 256 (1958), rev'd on other grounds, 278 F.2d 927 (5th Cir. 1960); Edwards v. Bomberg, 23x F.2d 107 (5th Cir. 1956); Morris Plan Co. of St. Joseph, 42 B.T.A. x190 (1940).
} 
In view of the confusion surrounding the casualty loss deduction, it is believed that a new statutory provision must be enacted if equitable, predictable results are to be achieved. An inherent weakness in the present statute is its attempt to define an economic loss in terms of the force causing the damage; the emphasis is placed on the force producing the loss rather than on the loss itself.

Possibly a deduction should be permitted for all permanent losses to a taxpayer's investment. In terms of economic loss, no distinction can be made between loss caused by moth damage and loss caused by fire. Yet, under present law the moth damage is nondeductible. ${ }^{32}$ Even though all permanent losses may warrant a deduction, loss of revenue and administrative difficulties would perhaps make such a system impractical. Therefore, it may be necessary to restrict the deduction. Even under the present concept of casualty loss, the taxpayer seeking a deduction is faced with additional diffculties which effectively restrict the operation of the deduction.

\section{Amount Deductible}

A taxpayer claiming a deduction must establish the amount of his loss. Under the present rule, the amount of the deductible loss is the difference between the value of the property immediately before and immediately after the casualty, not to exceed its basis and diminished by insurance or other compensation realized..$^{33}$ This formula seems

${ }^{39}$ Rev. Rul. 55-327, I955-1 Cum. Bull. 25.

${ }^{83} \mathrm{~J}$. H. Anderson, I7 P-H Tax Ct. Mem. 721,722 (1948): "The measure of a casualty loss on non-business property, deductible under $\left[\S_{65}(\mathrm{c})\right] \ldots$ is the difference between the fair market values of the property immediately preceding, and immediately after, the casualty, but not in excess of the cost [i.e., adjusted basis] or March I, 1913 value, and diminished by insurance [or other compensation] realized. Where property has actually depreciated in value, depreciation should be considered in determining the value, regardless of the fact that it was not deductible for income tax purposes in prior years." See Helvering v. Owens, 305 U.S. 468 (1939). Generally the adjusted basis of non-business property is the same as the unadjusted basis since there is no adjustment for depreciation. Sears v. United States, 3 A.F.T.R.2d 997 (D.C. Ohio 1959). For example, suppose that a house was purchased in 1945 for $\$ 10,000$. In $196 \mathrm{I}$ it is partially destroyed by fire. If, by competent appraisal, its value before and after the fire is established to be $\$ 25$,000 and $\$ 15,000$ respectively, $\$ 10,000$ may be deducted, since the amount of the deduction is not greater than the basis (here cost) of the property. As another example, suppose the appraised values before and after the fire had been $\$ 25,000$ and $\$ 10,000$ respectively. In this situation the taxpayer's deduction would be limited to $\$ 10,000$, since the deduction may not exceed the cost of the house.

The deduction is also limited by the amount of insurance coverage on the property. It should be noted that insurance recovery is not taken into account until the loss in 
simple enough, but its implementation has proven exceedingly diffcult.

The classic examples arose out of an ice storm. In one case the taxpayer, owner of a farm covered with valuable forests, sought a deduction of $\$ 3,000$, claiming that the value of the property before and after the ice storm was $\$ I 75,000$ and $\$ I 72,000$ respectively. Testimony of a licensed real estate broker corroborated the taxpayer's contention. The District Commissioner offered no evidence as to value, contending that there was no basis for the claimed deduction. The deduction was perfunctorily disallowed. ${ }^{34}$ However, another taxpayer whose property was damaged in the same storm was allowed a deduction on the basis of testimony of a competent forester who carefully described the damage to petitioner's shade trees. ${ }^{35}$

As noted above, the deductible loss may not exceed the basis of the property. However, where shrubbery and trees used for landscape purposes are damaged, the courts have held that the deduction is determined by the resulting decrease in value of the entire estate. The only apparent ceiling is the total adjusted basis of the property. ${ }^{30}$ An example is the Louisiana case in which cedar trees surrounding the taxpayer's home were killed by frost. The trees represented only a small part of the purchase price of the land but appeared to have been worth $\$ 17,000$ to the total value of the estate. A deduction in that amount was allowed, the court intimating that it thought the loss in value to the property was even more than was claimed. ${ }^{37}$

In determining the amount of a casualty loss, the fair market value of the property immediately before and immediately after the casualty should be ascertained by competent appraisal. However, the appraisal must recognize any general market decline in order that the deduction be limited to the actual loss resulting from the damage to the prop-

value is first determined as above. For example, if before and after values were $\$ 20,000$ and $\$ 5,000$ and the taxpayer had $\$ 8,000$ insurance coverage, the loss would be limited to $\$ 2,000$ ( $\$ 10,000-\$ 8$,000 maximum allowable) instead of $\$ 7,000$ (the actual loss to taxpayer figured on the value estimates. $\$ 20,000-\$ 5,000=\$ 15,000-\$ 8,000$ $=\$ 7,000)$.

${ }^{34}$ Anne B. Richardson, 1 B.T.A. 576 (1925).

${ }^{35}$ Whipple v. United States, 25 F.2d 520 (D.C. Mass. 1938).

${ }^{\text {ab }}$ Harry M. Leet, 24 P-H Tax Ct. Mem. 32 (1955), aff'd, 230 F.2d 845 (6th Cir. 1956); Jay W. Howard, 28 P-H Tax Ct. Mem. 359 (1959); S. F. Horn, 28 P.H Tax Ct. Mem. I55 (1955); William O. Lindley, 2 I P-H Tax Ct. Mem. 323 (1952).

${ }_{\mathrm{s}}$ United States v. Barret, 202 F.2d 804 (5th Cir. 1953). If the property is owned as tenants by the entirety, the husband can deduct only one half of the loss. Gilbert $J$. Kraus, 20 P-H Tax Ct. Mem. 983 (r 95 r). 
erty ${ }^{38}$ For example, if a storm generally depresses prices in a particularly area, this decrease in value may not be deducted as a casualty loss.

In $1955^{38}$ the Service ruled that while cost of repairs, restoration, clearing up, or removing debris cannot be used as a measure of the loss, value immediately after the casualty means the value before the property is repaired, restored, or cleared up. Repair is only some evidence to be considered along with expert appraisal. Some courts, however, have expressed dissatisfaction with the before-and-after value test, ${ }^{40}$ and determinations of loss based on cost of repair have frequently been approved. ${ }^{41}$ For example, in Robert H. Montgomery ${ }^{42}$ a casualty loss deduction based on the estimated cost of repair was allowed. The court, noting that the value of the property before and after the loss was a question of fact, chose to use the repair estimate rather than real estate appraisers' estimates of market value.

The value test places a difficult, uncertain task on a taxpayer, and the courts have often refused to accept the figures offered by him. A greater degree of certainty and less costly litigation might result if the lower of the cost of repairs or the cost of replacement were accepted. However, the repair or replacement method of arriving at the amount of a deductible loss is not a complete solution to the problems here. For example, where there has been no actual repair, the taxpayer would have to furnish a mere estimate, which would raise essentially the same problems as do value estimates. The value method has been hammered out through usage to a point where it is at least capable of uniform application. The difficulty is in proof. Even this is not too great an obstacle if the taxpayer does not content himself with hastily formed estimates of value but buttresses his claim with carefully prepared records of the loss. However, unless there is a sharp break with the present case law, the most certain prediction of the amount of allowable loss is the repair bill.

The requirement that the amount of the claim be supported by

${ }^{38}$ West v. United States, I6 3 F. Supp. 739 (E.D. Pa.), aff'd, 259 F.2d 704 (3d Cir. 1958).

${ }^{30}$ IR-Cir. 55-II.

${ }^{40}$ See, e.g., Gilbert J. Kraus, 20 P-H Tax Ct. Mem. 983 (I95I).

${ }^{11}$ E.g., W. F. Harmon, I3 T.C. 373 (1949).

42 I 6 P-H Tax Ct. Mem. 66 (1947) (damage to Florida estate by freeze). The court while accepting testimony by both commissioner's and taxpayer's experts, chose to allow the amount of replacement estimated by the gardener a few days after the freeze. 
explicit proof of actual loss is also reflected in the limitation on the deduction to losses of the taxpayer's own property. What does "property" mean in this context?

\section{The Physical Damage Reouirement}

A forest fire destroys the view from taxpayer's hillside residence. His property is not damaged by the fire; yet, its value decreases because the view is gone. Can the taxpayer deduct this loss in value?

Under the generally accepted rule, the answer is no because the taxpayer's property has not been physically damaged. ${ }^{43}$ Mere loss in value does not entitle the taxpayer to a deduction. In West v. United States $^{44}$ the taxpayer owned a summer cottage on a lake owned by an incorporated social club of which she was a member. Use of the lake facilities was a privilege of membership. A hurricane destroyed the retaining dam, resulting in total destruction of the lake. The value of taxpayer's property dipped sharply thereafter, and she attempted to deduct the reduction in value as a casualty loss from the storm. The deduction was denied because the loss of the lake was not a loss of taxpayer's property, but a loss to the corporation. Similarly, it has been held that devaluation of beach property due to a storm is not an allowable deduction where the decline in value does not result from physical damage caused by the storm, but is caused by fear of future storm damage on the part of prospective buyers. ${ }^{45}$

The physical damage requirement produced an absurd result in Citizens Bank of Weston v. Commissioner. ${ }^{40}$ After a flood inundated the basement of taxpayer's property, the bank was forced to discontinue use of the basement for the storage of important records and files. In effect, an important part of the building became virtually worthless with a concomitant decrase in the building's value. Yet, the court denied the deduction. In this case the taxpayer would necessarily make expenditures to insure safe storage facilities for its records. A1though an economic loss was suffered as a result of the flood, prior cases gave the court ample authority for requiring that actual physical damage accompany a deductible loss. ${ }^{47}$

Even though the statutory language does not explicitly require

\footnotetext{
${ }^{43}$ W. S. Dickason, 20 B.T.A. 496 (1930); Samuel E. Mulholland, 16 B.T.A. 1331 (1929); B. M. Peyton, 10 B.T.A. 1129 (1928).

${ }^{44}{ }_{16}$ F. Supp. 739 (E.D. Pa.), aff'd, 259 F.2d 704 (3d Cir. x958).

${ }^{45}$ Frank P. Kendall, 27 P-H Tax Ct. Mem. 695 (1958).

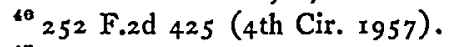

${ }^{47}$ E.g., C. W. Stoll, 15 P-H Tax Ct. Mem. 685 (1946).
} 
actual physical damage to the taxpayer's property, the case law was fairly consistent in this respect until the unheralded case from Mississippi, Stowers v. United States. ${ }^{48}$ There, a taxpayer sought to deduct loss of value to his property caused by a slide of a river bank near the taxpayer's home which damaged a city street normally used by the taxpayer to reach his property. Although the property was not physically damaged, a deduction was allowed. The court repudiated the requirement of physical damage, stating: ${ }^{49}$

The question arises as to how ... [plaintiff's property] ... was damaged in so large amount if the physical property was not affected. Such a damage arises because the residence was no longer useful .... It is fundamental that land has no value aside from the use that might be made of it. Plaintiff's residence was rendered useless and, without access from a street ... its value was destroyed.

Under the Stowers case the taxpayer in the above hypothetical situation might be permitted a deduction since the destruction of the view resulted in an economic loss to the homeowner. However, the decision raises far more problems than might first appear. Under this case, the entire Florida Keys could be devalued and a deduction taken by landowners because of partial destruction of the overseas highway. And yet it is apparent that the "losses" here are only temporary. The situation presented in the Stowers case is strikingly similar. The road in that case will probably be rebuilt, restoring any loss previously deducted. An interesting question might then arise as to whether the taxpayer would be required to include the increase in the value of his property due to the restoration of the road in his taxable income.

It appears that there are two reasons for the physical damage requirement. First, it is possibly an application of the general rule that a loss is not deductible unless actually sustained. For example, it is well settled that a taxpayer may not take a deduction for loss in value of securities. ${ }^{50}$ Unless the stock becomes completely worthless there must first be some transfer of the stock, usually a sale, which will definitely fix the amount of financial loss. ${ }^{51}$ The courts have perhaps

\footnotetext{
${ }^{18}$ I69 F. Supp. 246 (S.D. Miss. 1958).

${ }^{10} \mathrm{Id}$. at 248. (Emphasis added.)

${ }^{50}$ W. P. Davis, 6 B.T.A. 1267 (1927); E. O. Walgren, 4 B.T.A. I066 (1926); Chicago Ry. Equip. Co., 4 B.T.A. 452 (1926); Augustus C. Adams, I B.T.A. 983 (1925).

${ }^{11} \mathrm{~A}$ deduction may be allowed even though the stock has not been transferred if the taxpayer can prove that the stock has become completely worthless. C. E. Conover
} 
felt that in the absence of actual physical damage a claimed loss is too speculative to meet the requirement that it be actually sustained. The second reason for requiring physical damage would seem to be judicial distrust of before-and-after value estimates. The cases indicate that a deduction is allowable only where there is some clear-cut financial loss that can be tied to the probable out-of-pocket expense to a taxpayer as a result of a casualty. One court even denied a deduction for damage done to taxpayer's automobile by salt water, noting that the claimant was still operating the unrepaired car. ${ }^{52}$ Yet, under the valuation test this factor is completely immaterial.

\section{ConCLUSION}

The present statutory provision allowing the deduction of casualty losses is at best vague and difficult to apply. As a result, the courts are given little specific guidance in determining whether a particular loss falls within the concept of "other casualty." The resulting body of case law that has developed from diverse judicial interpretation of the statute provides little aid to the taxpayer who is required to bear the expense and inconvenience of litigating a contested deduction. The Internal Revenue Service, having largely accepted the courts' confused piecemeal implementation of the statute, has failed to dispel the uncertainty here.

The confusion and inequity surrounding this statutory provision stems from the difficulties inherent in application of a test of deductibility that seeks to define a deductible loss in terms of the force producing the loss rather than the loss itself. The Code in requiring that a deductible loss result from an uncompensated "casualty" causes the issue of deductibility to turn on the definition of a term unfamiliar to the common law and not defined by statute. Consequently, the courts are given no guideposts in their efforts to define the scope of the deduction.

In view of the labyrinth produced by the operation of the present statute, it is believed that a new section should be enacted. To achieve a measure of equality, the question of deductibility should be answered in terms of the losses for which a deduction will be permitted rather than the force causing the loss. Under optimum conditions the taxpayer might be allowed to deduct all economic losses sustained, except-

Co., 7 B.T.A. 1234 (1927). INT. REv. CODE of 1954, § 165 (g). See generally, 2 CCH 196r Stand. Fed. TAX ReP. I 1555.

${ }^{52}$ Edward W. Banigan, 20 P-H Tax Ct. Mem. 511 (1951). 
ing only losses resulting from the taxpayer's willful destruction of his property. ${ }^{53}$ However, the resulting loss of tax revenue might make such an omnibus deduction unfeasible. ${ }^{54}$

Admittedly, there is no easy solution to the problems presented by the casualty loss deduction. Yet, the haphazard, illogical coverage of the present deduction demands that a legislative effort be made to delineate the purpose ${ }^{55}$ and operation ${ }^{56}$ of the casualty loss deduction.

${ }^{53}$ Such a result could be achieved by repealing $\$$ I $_{65}(\mathrm{c})$. If this were done, the only applicable provision would be the general rule set out in $\S 165(\mathrm{a})$, which allows a deduction for "any loss sustained during the taxable year and not compensated for by insurance or otherwise." An exception disallowing deduction of losses caused by the taxpayer's willful destruction of his property undoubtedly would be read into the statute by the courts.

su As an alternative "solution" to the problems presented here, Congress might repeal only the third subsection of $\S{ }_{16}(\mathrm{c})$, thereby limiting deductible losses to those "incurred in a trade or business" ( $(165(\mathrm{C})(\mathrm{I}))$ and those sustained in "any transaction entered into for profit, though not connected with a trade or business" ( $\left.\S 16_{5}(\mathrm{c})(2)\right)$.

Keeping in mind the naxim that deductions are "a matter of legislative grace," an even more drastic "solution" would be repeal of $\S 165$ in toto.

${ }^{65}$ If the statute included some indication of the policy factors that contribute to the allowance of a deduction here, the courts would perhaps be able to develop a theory of casualty loss deduction.

"If the statute were amended to strike the term "other casualty," the problem of defining deductible losses would subsist. It is believed that the most feasible solution here would be to retain the general rule of deductibility found in $\S 165(a)$ and incorporate subsections providing for specific exceptions. Thus, if "legislative grace" does not include allowance of a deduction for the value of mislaid or lost property, Congress should so state. While problems of interpretation and construction would still exist, the relative certainty that would result commends this task to Congress. 